\title{
Development of Lean Assessment Tool for Healthcare Industry
}

\author{
Dodgalih Nur Muhammad, Putu Dana Karningsih \\ Department of Systems and Industrial Engineering, Institut Teknologi Sepuluh Nopember, Surabaya, \\ Indonesia \\ e-mail:dodgalih7@gmail.com
}

\begin{abstract}
The concept of lean is originated in manufacturing industry. However, this concept also has been widely adopted in service industry, from airlines to retailers. There are several healthcares or hospitals in various countries that has implemented Lean. The hospital that has adopted lean, shown various improvements, such as increase on efficiency and flexibility, reduction cost and infections cases. It is important to have lean assessment to measure leanness level after implementing lean. Lean Assessment Tool is utilized to measure effectiveness and efficiency of lean implementation in a particular company. There are many studies on Lean Assessment Tool for manufacturing and service industry in general. However, Lean Assessment Tool that is specific for hospital is not yet available. Therefore this study aims to develop a Lean Assessment Tool (LAT) for healthcare. First, quantitative and qualitative dimensions and indicators are gathered from literature study. Proposed dimensions and indicators are then selected and validated using the Fuzzy Delphi method. There are seven quantitative dimensions, which are quality, time, internal transportation, employee involvement, cost, customer, and inventory. While, there are six qualitative dimensions, which are quality, process, employee involvement, vertical information system, technology upgrading, and management commitment. Measurement method by using fuzzy logic to calculate leanness level for both quantitative and qualitative indicator is then applied. Leanness level will be mapped using radar plots.
\end{abstract}

Keywords - Lean Assessment, lean service, lean measurement, lean healthcare.

\section{INTRODUCTION}

L EAN concept was developed by Toyota with the term of Toyota Production System (TPS). The main purpose of TPS is that companies are able to produce goods or services at the lowest possible cost. According to Gaspersz [1], lean is an approach that is carried out continuously to identify and eliminate waste or non value added activities on goods and services products. Thus it can be concluded that lean aims to reduce waste in the production system so that the performance of the system increases significantly [2].

Lean implementation has been carried out in the manufacturing industry for more than three decades [3]. However, since 1998 [4] the application of lean concept has not only been used in manufacturing companies, but has penetrated into the services, trade and public sector sectors [5]. The service industry is growing rapidly and currently has a greater economic influence compared to the manufacturing industry. One of the service industries that experienced the largest economic growth is health service sector and social activities. Based on BPS data, economic growth in the health service sector and social activities between 2014 and 2019 in Indonesia have an average growth of 6,903\%. The health services and social activities sector consists of six subsectors, namely health institution services, health workforce services, health support services, special transportation services for transporting the sick, animal health services and social activity services.

Hospital is one of the business sectors in the health service sector and social activities. According to [6], hospitals can be said to be efficient if they are able to use their resources to do value added activities as well as provides a good quality services. Farrell [7] suggests that the best approach to provide quality in services efficiently by applying lean approach. One of the hospitals in Indonesia that has implemented lean concept is Kemang Medical Care Hospital in Jakarta. The lean implementation was carried out in 2013. It shows that there is $100 \%$ productivity (zero waste) and the patient satisfaction index increased from $76 \%$ to $87 \%$ [8].

Narayanamurthy and Gurumurthy [9] divides lean implementation into three stages, which are readiness for lean implementation, lean implementation, and lean assessment. The lean assessment stage is the stage that measures the leanness level of a company in implementing lean. Leanness measurement is done to find out whether the company is improving after lean implementation. Thus, the company can make continuous improvement based on the results of these leanness level measurements. A tool is needed to make it easier to do lean assessment in companies. Lean assessment tool (LAT) is also able to carry out a thorough examination of the performance of lean practices, and is able to identify lean improvement [10]. Lean assessment tool uses dimensions with each indicator as a benchmark. These indicators represent waste that occurs in the company and represent the company's performance.

Based on the existing literature review, the lean assessment tool is mostly aimed at manufacturing industry. There is only one tool proposed for service industry in general. Lean assessment tools in the manufacturing industry have dimensions and indicators that are different from the service industry. The difference in indicators is due to the characteristics of the service industry that are different from the manufacturing industry. Specific characteristics for the service industry are intangibility, inseparability, variability and perishability. The difference does 
International Conference on Business and Engineering Management 2020 (IConBEM 2020)

February $1^{\text {st }}$ 2020, Institut Teknologi Sepuluh Nopember, Surabaya, Indonesia not only occur between manufacturing LAT and services, but between manufacturing LAT has its own dimensions and indicators. Thus, it can be concluded that each study proposing LAT for manufacturing and services has different dimensions and indicators. But only Pakdil and Leonard [11] classify the indicators into quantitative and qualitative manner. Thus, their frameworks is able to measure company leanness level more accurately and more thoroughly than other proposed LATs.

\section{METHOD}

Implementation of lean in hospitals has been done in many previous studies, but there is no lean assessment tool that specifically measures the specific leanness level of hospital. In this research, a specific lean assessment tool is developed to be used in hospitals. The development is done on indicators used to measure hospital leanness, because the indicators are different from the manufacturing industry and the service industry in general. The development of lean assessment tool is carried out through several stages, the first stage is determining dimensions and indicators obtained from literature review related to LAT for manufacturing and service, lean implementation in hospitals, service quality in hospitals, key performance indicators (KPI) in hospitals. These dimensions and indicators then are selected based on expert opinions using fuzzy Delphi. It is conducted through questionnaires and interviews to five experts through several rounds. Similar to Pakdil and Leonard [11], this study also proposes two types of indicators, quantitative and qualitative. The second step is determining the leanness level measurement using fuzzy logic and maturity level. The third step is determining the mapping of the leanness level using radar plots.

\section{RESULT AND DISCUSSION}

\section{A. LAT Dimensions and Indicators Development}

The initial stage in developing LAT is to collect and select dimensions and indicators. The collection of dimensions was carried out by conducting a literature review on previous research with the LAT topic carried out in the manufacturing industry and the service industry in general. The selection of dimensions was based on eight previous studies that proposed LAT, including seven LAT studies for the manufacturing industry and one LAT study for the service industry in general. Seven LAT studies for the manufacturing industry include Karlsson and Ahlstrom [12], Soriano-Meier and Forrester [13], Bayou and de Korvin [14], Wan and Chen [15], Vinodh and Chintha [16], Kumar et al. [17], and Pakdil and Leonard [11]. While one LAT study for the service industry in general is research from Malmbrandt and Ahlstrom [18]. The dimensions used in previous studies vary. So that in this study the selection of the appropriate dimensions to represent the indicators to be used.

In addition to review literatures proposing the LAT model (dimensions and indicators) in Table 1.
This study also reviews previous studies related to the implementation of lean, service quality and key performance indicators (KPI) in hospitals. The summary of these studies can be seen in table 2. Based on the literature review (table 1 and table 2), the development of LAT for hospitals does not use all the dimensions used in LAT for the manufacturing industry. There are 11 dimensions used in hospitals, namely quality, cost, time, internal transportation, inventory, employee involvement, process, customer, vertical information system, technology upgrading, and management commitment. After determining the dimensions that can be used for hospitals, then choose indicators that are able to reflect the waste that occurs in hospitals.

Table 3 shows the results of the literature review to get indicators that can describe the waste that occurs in hospitals. There are 47 indicators that describe the waste that occurs in hospitals. Each indicator is grouped into dimensions according to the definition of that dimension.

The quality dimension describes the measurement of the quality of services provided to patients. This dimension is an important dimension, where this dimension measures activities that are directly related to patients who are the core of the service industry. This quality dimension relates to the measurement of waste errors and duplication that occur in the service industry. Based on the results of the literature review conducted, the indicators used in the quality dimension are (Q1) mortality rate, (Q2) input patients' identity correctly and completely, (Q3) employee competencies (nurses, pharmacists, nutritionists, radiographers and medical recorders) in carrying out work, (Q4) doctor competencies in carrying out tasks according to job desk, (Q5) accuracy of Triage (grouping patients based on severity of trauma or disease), (Q6) cancellation of the action or treatment rate, (Q7) surgeries repetition rate, (Q8) ask the patient or family for approval of high-risk actions (surgeries, anesthesia, etc.) to be performed, (Q9) doctors and employees competencies in using new machinery or equipment.

The time dimension describes the measurement of the time a patient experiences when a patient arrives for registration until the patient pays and leaves the hospital. This dimension measures the speed and efficiency of services performed by the hospital to patients. The faster / less time experienced by patients, the more efficient the services provided and make patient satisfaction increase. This time dimension relates to the measurement of waste delay that occurs in the service industry. Based on the results of the literature review conducted, indicators used in the time dimension are (T1) LOS (length of stay) time, (T2) registration waiting time, (T3) cashier waiting time, (T4) waiting time for radiology results (X-ray, MRI, CT scan, PET scan, etc.), (T5) waiting time for laboratory results, (T6) pharmacy waiting time, (T7) waiting time for doctor's examination, (T8) Triage waiting time (grouping patients based on severity of trauma or disease), (T9) discharge time, (T10) 
International Conference on Business and Engineering Management 2020 (IConBEM 2020)

February $1^{\text {st }}$ 2020, Institut Teknologi Sepuluh Nopember, Surabaya, Indonesia

Table 1.

Dimensions of The Past Research LAT

\begin{tabular}{|c|c|c|c|c|c|c|c|c|}
\hline Dimensions & $\begin{array}{c}\text { Karlsson and } \\
\text { Ahlstrom } \\
\text { [12] }\end{array}$ & $\begin{array}{c}\text { Soriano- } \\
\text { Meier dan } \\
\text { Forrester } \\
{[13]} \\
\end{array}$ & $\begin{array}{l}\text { Bayou and } \\
\text { de } \\
\text { Korvin [14] }\end{array}$ & $\begin{array}{c}\text { Wan and Chen } \\
{[15]}\end{array}$ & $\begin{array}{l}\text { Vinodh and } \\
\text { Chintha [16] }\end{array}$ & $\begin{array}{c}\text { Kumar et al. } \\
\text { [17] }\end{array}$ & $\begin{array}{l}\text { Malmbrandt and } \\
\text { Ahlstrom [18] } \\
\text { (Service) }\end{array}$ & $\begin{array}{l}\text { Pakdil and } \\
\text { Leonard [11] }\end{array}$ \\
\hline Quality & $\checkmark$ & $\checkmark$ & & & $\checkmark$ & & $\checkmark$ & $\checkmark$ \\
\hline Time & $\checkmark$ & $\checkmark$ & & $\checkmark$ & $\checkmark$ & & $\checkmark$ & $\checkmark$ \\
\hline $\begin{array}{l}\text { Internal } \\
\text {. }\end{array}$ & $\checkmark$ & $\checkmark$ & & & $\checkmark$ & & & $\checkmark$ \\
\hline Inventory & $\checkmark$ & $\checkmark$ & $\checkmark$ & & $\checkmark$ & & $\checkmark$ & $\checkmark$ \\
\hline Product Value & & & & $\checkmark$ & & & & \\
\hline Process & & & & & $\checkmark$ & $\checkmark$ & $\checkmark$ & $\checkmark$ \\
\hline Customer & & & & & $\checkmark$ & $\checkmark$ & $\checkmark$ & $\checkmark$ \\
\hline $\begin{array}{l}\text { Continuous } \\
\text { Improvement } \\
\text { Vertical }\end{array}$ & $\checkmark$ & $\checkmark$ & & & & & $\checkmark$ & $\checkmark$ \\
\hline $\begin{array}{l}\text { Technology } \\
\text { Upgradation }\end{array}$ & & & & & $\checkmark$ & $\checkmark$ & & \\
\hline $\begin{array}{l}\text { Management } \\
\text { Commitment }\end{array}$ & & & & & $\checkmark$ & & $\checkmark$ & \\
\hline
\end{tabular}

Table 2.

Dimensions of The Proposed LAT

\begin{tabular}{|c|c|c|c|c|c|c|c|c|c|c|c|c|c|c|c|c|}
\hline Dimensions & 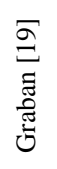 & 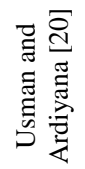 & 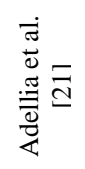 & 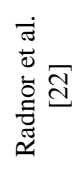 & 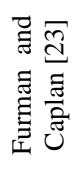 & 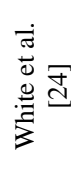 & 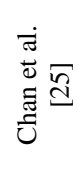 & 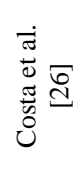 & 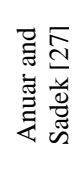 & 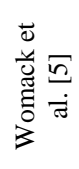 & 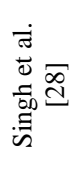 & 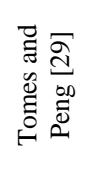 & 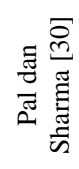 & $\begin{array}{l}\overrightarrow{\bar{m}} \\
\dot{\vec{\sigma}} \\
\vec{u} \\
\dot{\omega}\end{array}$ & 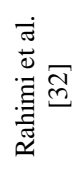 & $\begin{array}{c}\text { This } \\
\text { Research }\end{array}$ \\
\hline Quality & $\checkmark$ & $\checkmark$ & & & & & & $\checkmark$ & & & $\checkmark$ & $\checkmark$ & & $\checkmark$ & $\checkmark$ & $\checkmark$ \\
\hline Cost & $\checkmark$ & & & $\checkmark$ & $\checkmark$ & & & $\checkmark$ & & $\checkmark$ & $\checkmark$ & & $\checkmark$ & & $\checkmark$ & $\checkmark$ \\
\hline Time & $\checkmark$ & $\checkmark$ & & $\checkmark$ & $\checkmark$ & $\checkmark$ & $\checkmark$ & $\checkmark$ & & $\checkmark$ & $\checkmark$ & $\checkmark$ & $\checkmark$ & $\checkmark$ & $\checkmark$ & $\checkmark$ \\
\hline $\begin{array}{c}\text { Internal } \\
\text { Transportation }\end{array}$ & & $\checkmark$ & $\checkmark$ & $\checkmark$ & $\checkmark$ & & & & & $\checkmark$ & & & $\checkmark$ & & & $\checkmark$ \\
\hline Inventory & & & & & & & & & & $\checkmark$ & & & & & & $\checkmark$ \\
\hline $\begin{array}{l}\text { Employee } \\
\text { Involvement }\end{array}$ & & $\checkmark$ & & $\checkmark$ & & & & & $\checkmark$ & & $\checkmark$ & & & $\checkmark$ & $\checkmark$ & $\checkmark$ \\
\hline Product Value & & & & & & & & & & & & & & & & \\
\hline $\begin{array}{l}\text { Process } \\
\text { Customer }\end{array}$ & & & $\checkmark$ & & $\checkmark$ & & & $\checkmark$ & $\checkmark$ & & $\checkmark$ & $\begin{array}{l}\checkmark \\
\checkmark\end{array}$ & $\checkmark$ & $\begin{array}{l}\checkmark \\
\checkmark\end{array}$ & $\begin{array}{l}\checkmark \\
\checkmark\end{array}$ & $\begin{array}{l}\checkmark \\
\checkmark\end{array}$ \\
\hline $\begin{array}{l}\text { Continuous } \\
\text { Improvement } \\
\text { Vertical }\end{array}$ & & & & & & & & & & & & & & & & \\
\hline $\begin{array}{l}\text { Information } \\
\text { System }\end{array}$ & & $\checkmark$ & & & & & & & $\checkmark$ & & $\checkmark$ & $\checkmark$ & $\checkmark$ & & & $\checkmark$ \\
\hline $\begin{array}{l}\text { Market Share } \\
\text { Supplier }\end{array}$ & & & & & & & & & & & & & & & & \\
\hline $\begin{array}{l}\text { Technology } \\
\text { Upgradation }\end{array}$ & & & & & & & & $\checkmark$ & & & $\checkmark$ & & $\checkmark$ & & & $\checkmark$ \\
\hline $\begin{array}{l}\text { Management } \\
\text { Commitment }\end{array}$ & & & & & & & & & $\checkmark$ & & & & & & & $\checkmark$ \\
\hline
\end{tabular}

process time for excellent service registration (surgeries / surgeries, hemodialysis (dialysis), ICU, chemotherapy, physiotherapy, etc.).

The internal dimensions of transportation describe the measurement of transportation activities carried out in a hospital. This dimension relates to the measurement of unnecessary movement waste that occurs in the service industry. Based on the results of the literature review conducted, the indicators used in the internal dimensions of transportation are (S1) time of drug delivery from the pharmacy to inpatients, (S2) the patient moves rooms to take action or check up.

The process dimension describes the measurement of the successful implementation of lean that has been done at the hospital. Implementation of lean measured is a lean tool related to the process carried out to be more effective and efficient. This process dimension relates to the measurement of unnecessary 
International Conference on Business and Engineering Management 2020 (IConBEM 2020)

February $1^{\text {st }} 2020$, Institut Teknologi Sepuluh Nopember, Surabaya, Indonesia

Table 3.

Dimensions and Indicators of The Proposed LAT

\begin{tabular}{|c|c|c|c|c|c|}
\hline Dimensions & Code & Indicators & Dimensions & Code & $\begin{array}{l}\text { Indicators } \\
\end{array}$ \\
\hline \multirow{9}{*}{ Quality } & Q1 & Mortality rate & Internal & $\mathrm{S} 1$ & $\begin{array}{c}\text { Time of drug delivery from the pharmacy } \\
\text { to inpatients }\end{array}$ \\
\hline & Q2 & $\begin{array}{l}\text { Input patients’ identity correctly and } \\
\text { completely }\end{array}$ & Transportation & $\mathrm{S} 2$ & $\begin{array}{c}\text { The patient moves rooms to take action or } \\
\text { check up }\end{array}$ \\
\hline & Q3 & $\begin{array}{l}\text { Employee competencies (nurses, pharmacists, } \\
\text { nutritionists, radiographers and medical } \\
\text { recorders) in carrying out work }\end{array}$ & \multirow{3}{*}{ Cost } & $\mathrm{C} 1$ & Total cost reduction \\
\hline & Q4 & $\begin{array}{c}\text { Doctor competencies in carrying out tasks } \\
\text { according to job desk }\end{array}$ & & $\mathrm{C} 2$ & $\begin{array}{l}\text { Ratio of BPJS / insurance patients to } \\
\text { general patients }\end{array}$ \\
\hline & Q5 & $\begin{array}{c}\text { Accuracy of Triage (grouping patients based } \\
\text { on severity of trauma or disease) }\end{array}$ & & C3 & The ratio of total revenue to total costs \\
\hline & Q6 & Cancellation of the action or treatment rate & \multirow{6}{*}{$\begin{array}{l}\text { Employee } \\
\text { Involvement }\end{array}$} & E1 & Coordination between employees / doctors \\
\hline & Q7 & Surgeries repetition rate & & E2 & Employees / doctors satisfaction rate \\
\hline & Q8 & $\begin{array}{l}\text { Ask the patient or family for approval of } \\
\text { high-risk actions (surgeries, anesthesia, etc.) } \\
\text { to be performed }\end{array}$ & & E3 & Employee / doctors turnover rate \\
\hline & Q9 & $\begin{array}{c}\text { Doctors and employees competencies in using } \\
\text { new machinery or equipment }\end{array}$ & & E4 & $\begin{array}{c}\text { Team to assess the data in doing } \\
\text { improvement work }\end{array}$ \\
\hline \multirow{10}{*}{ Time } & $\mathrm{T} 1$ & LOS (length of stay) time & & E5 & Employees give improvement suggestions \\
\hline & $\mathrm{T} 2$ & Registration waiting time & & E6 & $\begin{array}{c}\text { Employees show a good commitment } \\
\text { towards the hospital }\end{array}$ \\
\hline & $\mathrm{T} 3$ & Cashier waiting time & $\begin{array}{l}\text { Technology } \\
\text { upgradation }\end{array}$ & K1 & $\begin{array}{c}\begin{array}{c}\text { Updating technology for medical machines } \\
\text { or equipment }\end{array} \\
\end{array}$ \\
\hline & $\mathrm{T} 4$ & $\begin{array}{l}\text { Waiting time for radiology results (X-ray, } \\
\text { MRI, CT scan, PET scan, etc.) }\end{array}$ & \multirow{3}{*}{$\begin{array}{l}\text { Vertical } \\
\text { Information } \\
\text { System }\end{array}$} & V1 & $\begin{array}{l}\text { Two-way flow of information (from top } \\
\text { management to employees and vice versa) }\end{array}$ \\
\hline & T5 & Waiting time for laboratory results & & $\mathrm{V} 2$ & $\begin{array}{l}\text { The hospital provides written standards for } \\
\text { disposing of unneeded items (B3, etc.) }\end{array}$ \\
\hline & T6 & Pharmacy waiting time & & V3 & $\begin{array}{c}\text { The hospital provides a good } \\
\text { communication system }\end{array}$ \\
\hline & $\mathrm{T} 7$ & Waiting time for doctor's examination & \multirow{2}{*}{ Customer } & U1 & Patients satisfaction rate \\
\hline & $\mathrm{T} 8$ & $\begin{array}{l}\text { Triage waiting time (grouping patients based } \\
\text { on severity of trauma or disease) }\end{array}$ & & $\mathrm{U} 2$ & Patients complaints rate \\
\hline & T9 & Discharge time & \multirow{3}{*}{ Inventory } & $\mathrm{I} 1$ & $\begin{array}{c}\text { Medical equipment inventory turnover } \\
\text { ratio (thermometer, syringe, infusion } \\
\text { device, etc.) }\end{array}$ \\
\hline & $\mathrm{T} 10$ & $\begin{array}{l}\text { Process time for excellent service registration } \\
\text { (surgeries, hemodialysis, ICU, chemotherapy, } \\
\text { physiotherapy, etc.) }\end{array}$ & & $\mathrm{I} 2$ & Drug supply turnover ratio \\
\hline \multirow{5}{*}{ Process } & $\mathrm{P} 1$ & $\begin{array}{c}\text { Adopt 5S principle (sort, set in order, shine, } \\
\text { standardize, sustain) }\end{array}$ & & I3 & Blood supply turnover ratio \\
\hline & $\mathrm{P} 2$ & Implementation of improvement plans & \multirow{4}{*}{$\begin{array}{l}\text { Management } \\
\text { Commitment }\end{array}$} & M1 & $\begin{array}{c}\text { Management provides lean training to } \\
\text { employees to identify waste and its root } \\
\text { problems }\end{array}$ \\
\hline & P3 & $\begin{array}{c}\text { Mapping process flow to identify activities } \\
\text { that occur using VSM (Value Stream } \\
\text { Mapping) }\end{array}$ & & M2 & $\begin{array}{c}\text { Management provides a good reward } \\
\text { system }\end{array}$ \\
\hline & $\mathrm{P} 4$ & $\begin{array}{l}\text { Adopt visual management (give a clear visual } \\
\text { mark on the layout in the work area and } \\
\text { location direction) }\end{array}$ & & M3 & $\begin{array}{l}\text { Management shows a good leadership } \\
\text { attitude in implementing lean }\end{array}$ \\
\hline & P5 & $\begin{array}{c}\text { The complexity of medical and administrative } \\
\text { procedures }\end{array}$ & & & \\
\hline
\end{tabular}

Table 4.

7-Point Lingustics Scale

\begin{tabular}{ccc}
\hline \hline Scale & Definition & Fuzzy number \\
\hline 7 & Very strongly important & $(0.9,1.0,1.0)$ \\
6 & Very important & $(0.7,0.9,1.0)$ \\
5 & Important & $(0.5,0.7,0.9)$ \\
4 & Neutral & $(0.3,0.5,0.7)$ \\
3 & Unimportant & $(0.1,0.3,0.5)$ \\
2 & Very unimportant & $(0.0,0.1,0.3)$ \\
1 & Very strongly unimportant & $(0.0,0.0,0.1)$ \\
\hline \hline
\end{tabular}

movement waste that occurs in the company. Based on the results of the literature review conducted, the indicators used in the process dimension are (P1) adopt $5 \mathrm{~S}$ principle (sort, set in order, shine, standardize, sustain), (P2) implementation of improvement plans, (P3) mapping process flow to identify activities that occur using VSM (Value Stream Mapping), (P4) adopt visual management (give a clear visual mark on the layout 
International Conference on Business and Engineering Management 2020 (IConBEM 2020)

February $1^{\text {st }} 2020$, Institut Teknologi Sepuluh Nopember, Surabaya, Indonesia in the work area and location direction), (P5) the complexity of medical and administrative procedures.

The cost dimension is a dimension that measures costs incurred at a hospital. Although the cost dimension is not related to one of the waste that occurred, but the cost dimension is an important dimension because cost reduction is the main objective of lean implementation. Based on the results of the literature review conducted, the indicators used in the cost dimension are (C1) total cost reduction (C2) ratio of BPJS / insurance patients to general patients, (C3) the ratio of total revenue to total costs.

The employee involvement dimension is a dimension that measures the role of human resources in implementing lean and the hospital is able to make the most of the capabilities of the employees. This dimension also measures the culture that occurs within the hospital, where the hospital undergoes a culture change from traditional to lean culture. The employee involvement dimension is related to the waste people that occur in the company. Based on the results of the literature review conducted, indicators used on the employee involvement dimension are (E1) coordination between employees / doctors, (E2) employees / doctors satisfaction rate, (E3) employee / doctors turnover rate, (E4) team to assess the data in doing improvement work, (E5) employees give improvement suggestions, (E6) employees show a good commitment towards the hospital.

The technology upgradation dimension describes the measurement of updates to the machines or medical equipment used. These updates can make the services carried out more quickly and accurately. Based on the results of the literature review conducted, the indicators used on the technology upgrading dimension is (K1) updating technology for medical machines or equipment.

The dimensions of the vertical information system describe the measurement of the information system used in hospitals. Measurement of the information system is carried out to find out whether the information conveyed is clear at each level of management. This dimension is related to waste unclear communication that occurs in the service industry. Based on the results of the literature review conducted, the indicators used in the vertical information system dimensions are (V1) two-way information flow (from management op to employees and vice versa), (V2) the hospital provides written standards for disposing of unneeded items (B3, etc.), (V3) the hospital provides a good communication system.

The customer dimension is a dimension that measures patient satisfaction. Dimensions are important dimensions to measure, because patient satisfaction is the goal of the hospital. This customer dimension is related to waste opportunity lost. So if the value of this dimension is not good, then the hospital will be threatened not to get patients who do re-examination at the hospital again. Based on the results of the literature review conducted, the indicators used in the customer dimension are (U1) patients satisfaction rate, (U2) patients complaints rate.
The inventory dimension describes the measurements made on inventory in a hospital. This dimension is related to incorrect inventory waste that occurs in the service industry.

Based on the results of the literature review conducted, the indicators used in the inventory dimension are (I1) medical equipment inventory turnover ratio (thermometer, syringe, infusion device, etc.), (I2) drug supply turnover ratio, (I3) blood supply turnover ratio.

The management commitment dimension is a dimension that measures management commitment in implementing lean implementation in a sustainable manner. This dimension is an important dimension in implementing lean implementation, where management commitment is needed for lean implementation. Because without the commitment and responsibility of management in implementing lean, the employee will also not have a sense of commitment and responsibility to carry out lean implementation. Based on the results of the literature review conducted, indicators used in the dimensions of management commitment, namely (M1) management provides lean training to employees to identify waste and its root problems, (M2) management provides a good reward system, (M3) management shows a good leadership attitude in implementing lean.

\section{B. Delphi Method Round I}

Delphi questionnaire round I is a questionnaire containing 11 dimensions and 47 indicators obtained from the literature review. Delphi questionnaire round I aims to get expert opinion about the suitability of outcome indicators from the literature review with conditions in the hospital. In addition, experts can also add new indicators related to existing dimensions that can be applied to hospitals.

The results of the first round of Delphi show that there are a decrease of four indicators because it is not suitable as a lean measurement indicator in the hospital. Those four indicators are (Q6) cancellation of the action or treatment rate, (Q7) surgeries repetition rate, (T7) waiting time for doctor's examination, (S2) the patient moves rooms to take action or check up. Besides, there are no new indicators added by experts. The 43 lean indicators are then used as the Delphi round II questionnaire and experts will rate every indicators' level of importance.

\section{Delphi Method Round II}

43 indicators which are the results of round I Delphi questionnaire were used as material for round II questionnaire. Experts are expected to rate importance using a 7-point Likert scale, from very strongly unimportant to very strongly important. The assessment results are then converted into fuzzy number. Fuzzy number used is a triangular fuzzy number. The conversion of Likert scale number into fuzzy number is based on table 4.

The fuzzy number is then processed to determine whether the dimensions and indicators have reached consensus. Consensus is reached if the average distance of all indicators on one dimension is smaller than $0.2(\mathrm{~d} \leq 0.2)$ and the percentage of the distance of each indicator of each expert on one dimension has a value smaller than 0.2 which is greater than $75 \%$ [34]. 
Table 5.

Concensus of Dimensions

\begin{tabular}{|c|c|c|}
\hline Dimensions & Average value d & Percentage of total value $d \leq 0,2$ \\
\hline Quality & 0,050164 & $(35 / 35)^{*} 100=100 \%$ \\
\hline Time & 0,080718 & $(43 / 45) * 100=96 \%$ \\
\hline Internal transportation & 0,091384 & $(5 / 5) * 100=100 \%$ \\
\hline Process & 0,047045 & $(25 / 25) * 100=100 \%$ \\
\hline Cost & 0,059932 & $(15 / 15) * 100=100 \%$ \\
\hline Employee involvement & 0,077461 & $(30 / 30) * 100=100 \%$ \\
\hline Technology upgradation & 0,091384 & $(5 / 5) * 100=100 \%$ \\
\hline Vertical information system & 0,061968 & $(15 / 15) * 100=100 \%$ \\
\hline Customer & 0,091384 & $(10 / 10) * 100=100 \%$ \\
\hline Inventory & 0,061968 & $(15 / 15) * 100=100 \%$ \\
\hline Management commitment & 0,081578 & $(15 / 15) * 100=100 \%$ \\
\hline
\end{tabular}

Table 6.

Generic Definition of Maturity Levels

\begin{tabular}{cc}
\hline \hline & Generic Definition of Maturity Levels \\
\hline $\begin{array}{l}\text { Level 1 } \\
\text { Level 2 }\end{array}$ & $\begin{array}{c}\text { No adoption: problems are often explicit and solutions often focus on symptoms instead of causes } \\
\text { General awareness: start of searching for proper tools and methods, problem solving is becoming more structured. Informal } \\
\text { approach in a few areas with varying degrees of effectiveness }\end{array}$ \\
Level 3 & $\begin{array}{c}\text { Systematic approach: most areas involved, but at varying stages. Experimentation using more and more tools and methods and } \\
\text { employees start following-up work using metrics }\end{array}$ \\
Level 4 & $\begin{array}{c}\text { On-going refinement: all areas involved, but at varying stages. Improvement gains are sustained } \\
\text { Level 5 }\end{array}$ \\
& $\begin{array}{c}\text { Exceptional, well-defined, innovative approach: all areas are involved at the advanced level. Improvement gains are sustained } \\
\text { and challenged systematically. Innovative solutions to common problems, recognized as best practice/role model }\end{array}$ \\
\hline \hline
\end{tabular}

Determination of the distance of each indicator using equation 1.

$d(\tilde{m}, \tilde{n})=\sqrt{\frac{1}{3}\left[\left(m_{1}-n_{1}\right)^{2}+\left(m_{2}-n_{2}\right)^{2}+\left(m_{3}-n_{3}\right)^{2}\right]}$

Table 5 shows the results of consensus data processing for each dimension. The results of the processing prove that all dimensions have reached a consensus from the experts. Since it has reached consensus, there is no need to do another Delphi round. So, there are no indicators that are reduced or eliminated, so the indicators used are still 43 indicators on 11 dimensions. The 11 dimensions and 43 selected indicators are then used to assess the level of leanness at the hospital.

\section{Leanness Level Measurement}

This study uses the fuzzy logic method developed by Behrouzi and Wong [35] and uses benchmarks obtained from historical data or hospital standards that must be achieved. Fuzzy logic uses fuzzy sets to represent non-statistical, uncertain and linguistic values. Uncertainty in this model can be removed using fuzzy numbers and crisp numbers can be used for decision makers. Behrouzi and Wong [35] developed a flexible model that integrates measurements quantitatively and qualitatively and is able to combine metrics measured in different units through the calculation of the final score which has no dimension. Lean assessment is carried out in several steps, that is:

\section{1) Determine the Lean Dimensions to be Assessed}

The dimension used in the assessment is the outcome dimension from the literature review. There are 11 dimensions to be assessed.

2) Identify Indicators and Metric for Each Lean Dimension
The indicator used in the assessment is an indicator of the results of the Delphi method. There are 43 indicators to be assessed. The metrics used are according to each indicator to be assessed.

3) Determine the Fuzzy Area and Membership Function for Each Indicator Metric

Use points "a" and "b" as the best and worst value of each indicator metric. Point "a" indicates the best performance ever done based on historical data or standards that must be achieved. Point "b" indicates the worst performance ever performed based on historical data. Determination of lean values for each indicator can use equation 2 .

$\mu \tilde{\mathrm{A}}(x)=\left\{\begin{aligned} 1, & \text { if } x_{i} \leq a \\ 0, & \text { if } x_{i} \geq b \\ 1-\frac{\left(x_{i}-a\right)}{(b-a)}, & \text { if } a<x_{i}<b\end{aligned}\right.$

\section{4) Calculate Lean Value}

Calculation of lean values for each indicator is carried out. Then the lean value for each dimension is done by calculating the average of all the indicators on that dimension using equation 3.

$\frac{\sum_{j=1}^{m} \sum_{i=1}^{n_{j}} \frac{\mu \tilde{A}(x) i j}{n i}}{m} \times 100$

The metrics used for quantitative indicators differ from qualitative indicators. There are 8 dimensions that have quantitative indicators. And there are 24 indicators using a quantitative approach. Each indicator uses different metrics according to the measurement of the indicator.

There are 6 dimensions that have qualitative indicators. And there are 19 indicators using a qualitative approach. All qualitative indicators use metrics based on the general definition of maturity level developed by Nightingale and Mize [36] in table 6 . The specific description of the maturity level for each indicator differs according to the indicator. 


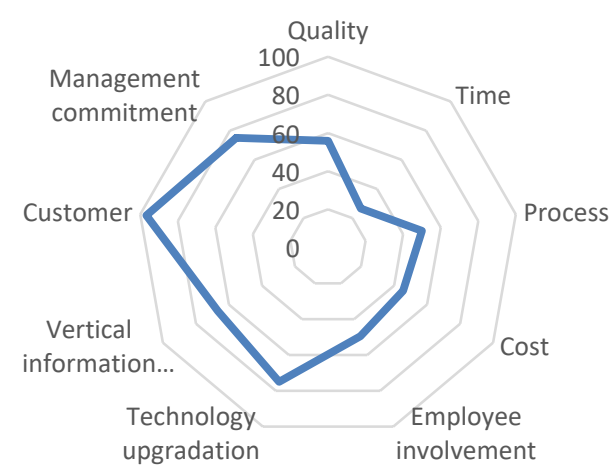

Figure 1. Radar Plot.

\section{E. Lean Value Mapping}

Lean value mapping needs to be done to provide a clear picture of how lean the company has adopted. Lean value mapping is done in each dimension. There are 11 lean values to be mapped, the mapping is using radar plots. Radar plots are used because radar plots are an important descriptive instrument for multivariate data and radar plots can be used in benchmark applications that have many performance measurements [37]. Radar plots can provide a more efficient picture for displaying a wide variety of data into one image [38].

In general, radar charts are radial plots that have a number of fingers / axes from the center. Each axis presents a score from one of the dimensions analyzed. The center point shows the score of 0 and the values in the circle indicate the level of leanness with a score of 100 on the outer circle. Mapping is carried out on the value of leanness in each dimension, so as to be able to show and compare clearly between dimensions that have not implemented lean well and dimensions that have implemented lean well. Analysis of radar plots can be used to make comparisons on one company with different time periods. So, the company can find out the direction of improvement that will be carried out to be able to always develop. Leanness level of each dimension are then aggregated by calculating the average value of the leanness of all dimensions to become a single value leanness level. The single value leanness level can then be used to compare the level of leanness with competitors. Figure 1 is an example of radar plots.

\section{IV.CONCLUSION}

Hospital lean assessment tool (H-LAT) is used to measure leanness level of hospital after implementing Lean. H-LAT has several dimensions and indicators. These dimensions and indicators were obtained based on literature review conducted on research on lean implementation in hospitals, service quality in hospitals and hospital key performance indicators (KPI). Dimension and indicators are then selected and validated using the fuzzy Delphi method. There are 11 dimensions and 43 indicators. The dimensions are as follow quality, cost, time, internal transportation, inventory, employee involvement, process, customer, vertical information system, technology upgrading, and management commitment.

Leanness level in H-LAT is then measured using fuzzy logic by using benchmarks obtained from historical data or standards that must be achieved by hospitals. Measurements were made on quantitatively and qualitatively indicators. Leanness level measurements on quantitative indicators are based on historical data. While leanness level measurements on qualitative indicators are based on interviews with experts at the hospital. Leanness level value calculation is performed on each dimension with each indicator.

Leanness level mapping on LAT uses radar plots because to provide a broader picture to show the dimensions that have been implemented lean well and the dimensions that need to make improvements. Mapping is done at the leanness level value of each dimension. Leanness level of each dimension are then aggregated by calculating the average value of the leanness of all dimensions to become a single value leanness level. The single value leanness level can then be used to compare the level of leanness with competitors.

\section{REFERENCES}

[1] Gaspresz, Vincent, "Lean Six Sigma for Manufacturing and Service Industries,”. Jakarta: PT. Gramedia Pustaka Utama, 2007.

[2] Achanga, P., Shehab, E., Roy, R., \& Nelder, G., "Critical success factors for lean implementation within SMEs," Journal of Manufacturing Technology Management, 17(4), 460-471, 2006.

[3] Stone, Kyle, "Four decades of lean: A systematic literature review," International Journal of Lean Six Sigma, 3, 112-132, 2012.

[4] Bowen, D. E., \& Youngdahl, W. E., "Lean service: in defense of a production-line approach,” International Journal of Service Industry Management, 9(3), 207-225, 1998.

[5] Womack, J., Byrne, A. P., Fiume, O. J., Kaplan, G. S., \& Toussaint, J, "Innovation series: going lean in health care," Institute for Healthcare Improvement, 21, 2005.

[6] Moraros, J., Lemstra, M., \& Nwankwo, C., "Lean interventions in healthcare: Do they actually work? A systematic literature review," International Journal for Quality in Health Care, 28(2), 150-165, 2016.

[7] Farrel, G., "Survey of ICT and Education in Africa," Washington, USA: The International Bank for Recpnstruction and Development, The World Bank Press (Buku Elektronik) diakses 5 Mei 2017, 2007.

[8] Iswanto, Heri., "Metode Kanban : Eliminasi Pemborosan Logistik Farmasi,” Diakses melalui http://hospitalindonesia.com/metode-kanbaneliminasi-pemborosan-logistik-farmasi/2/, 2014.

[9] Narayanamurthy, Gopalakrishnan \& Gurumurthy, Anand, "Leanness assessment: a literature review," International Journal of Operations \& Production Management, 36, 1115-1160, 2016.

[10] Oleghe, Omogbai \& Salonitis, Konstantinos, "A lean assessment tool based on systems dynamics,” Procedia CIRP, 50, 2016.

[11] Pakdil, F., \& Leonard, K. M., "Criteria for a lean organisation: Development of a lean assessment tool," International Journal of Production Research, 52(15), 4587-4607, 2014.

[12] Karlsson, C., \& Hlström, P., "Assessing changes towards lean production," International Journal of Operations and Production Management, 16(2), 24-41, 1996.

[13] Soriano-Meier, H., \& Forrester, P. L., "A model for evaluating the degree of leanness of manufacturing firms," Integrated Manufacturing Systems, 13(2), 104-109, 2002.

[14] Bayou, M. E., \& de Korvin, A., "Measuring the leanness of manufacturing systems-A case study of Ford Motor Company and General Motors," Journal of Engineering and Technology Management - JET-M, 25(4), 287-304, 2008. 
International Conference on Business and Engineering Management 2020 (IConBEM 2020)

February $1^{\text {st }} 2020$, Institut Teknologi Sepuluh Nopember, Surabaya, Indonesia

[15] Wan, H. Da, \& Frank Chen, F., "A leanness measure of manufacturing systems for quantifying impacts of lean initiatives,” International Journal of Production Research, 46(23), 6567-6584, 2008.

[16] Vinodh, S., \& Chintha, S. K., "Leanness assessment using multi-grade fuzzy approach. International Journal of Production Research, 49(2), 431445, 2011.

[17] Kumar, S., Singh, B., Qadri, M. A., Kumar, Y. V. S., \& Haleem, A., “A framework for comparative evaluation of lean performance of firms using fuzzy TOPSIS. International Journal of Productivity and Quality Management, 11(4), 371-392, 2013.

[18] Malmbrandt, M., \& Åhlström, P., “An instrument for assessing lean service adoption. International Journal of Operations and Production Management, 33(9), 1131-1165, 2013.

[19] Graban, M., "Lean Hospital : Improving Qualit, Patient Safety, and Employee Satisfaction,” New York: CRC Press, 2009.

[20] Usman, Indrianawati \& Ardiyana Nandini, Mira, "Lean Hospital Management, Studi Empirik pada Layanan Gawat Darurat,”, 2017.

[21] Adellia Yolla et al., "Lean Healthcare Approach for Waste Minimization at Malang Islamic Hospital of Unisma,” Jurnal ilmiah teknik industri, 29230, 2016.

[22] Radnor, Z.J., Holweg, M. \& Waring, J., "Lean in healthcare: The unfilled promise?,” Social Science \& Medicine, 74(3), 364-371, 2012.

[23] Furman, C. \& Caplan, R., "Applying the Toyota Production System: using a patient safety alert system to reduce error,” Joint Commission Journal on Quality and Patient Safety, 33(7), 376-386, 2007.

[24] White, B.A., Baron, J.M., Dighe, A.S., Camargo, C.A. Jr \& Brown, D.F., "Applying Lean methodologies reduces ED laboratory turnaround times," American Journal of Emergency Medicine, 33(11): 1572-1576, 2015.

[25] Chan, H., Lo, S., Lee, L. , Lo, W., Yu, W., Wu, Y., Ho, S., Yeung, R. \& Chan, J., "Lean techniques for the improvement of patients' flow in emergency department," World Journal of Emergency Medicine, 5(1), 248, 2014.

[26] Costa, L.B., Filho, M.G., Rentes, A.F., Bertani, T.M. \& Mardegan, R., "Lean healthcare in developing countries: evidence from Brazilian hospitals," International Journal of Health Planning and Management, 2015.
[27] Anuar, Azyyati \& Sadek, Daing, "Validity Test of Lean Healthcare using Lawshe's Method,” International Journal of Supply Chain Management. 7, 197-203, 2018.

[28] Singh, Ajwinder \& Prasher, Ajay \& Kaur, Navdeep, "Assessment of hospital service quality parameters from patient, doctor and employees' perspectives,” Total Quality Management \& Business Excellence, 1-20, 2018.

[29] Tomes, A. and Chee Peng Ng, S., "Service quality in hospital care: the development of an in-patient questionnaire," International Journal of Health Care Quality Assurance, Vol. 8 No. 3, pp. 25-33, 1995.

[30] Pal, Sourabh and Santosh kumar Sharma, "Integrated Lean Six Sigma Approach for Healthcare Service Quality Management,” 2017.

[31] Si, Sheng-Li \& You, Xiao-Yue \& Liu, Hu-Chen \& Huang, Jia., "Identifying Key Performance Indicators for Holistic Hospital Management with a Modified DEMATEL Approach. Internationa," Journal of Environmental Research and Public Health, 14, 934 , 2017.

[32] Rahimi, Hamed \& Kavosi, Zahra \& Shojaei, Payam \& Kharazmi, Erfan, "Key performance indicators in hospital based on balanced scorecard model,” Journal Health Management \& Informatics, 4, 17-24, 2017

[33] Kamarulzaman, N., Jomhari, N., Mohd Raus, N., \& Zulkifli Mohd Yusoff, M., "Applying the Fuzzy Delphi Method to Analyze the user Requirement for user Centred Design Process in Order to Create Learning Applications,” Indian Journal of Science and Technology, 8(32), 2015.

[34] Cheng, C.-H., \& Lin, Y., "Evaluating the best main battle tank using fuzzy decision theory," European Journal of Operational Research, 142, 174186, 2002.

[35] Behrouzi, F., \& Wong, K. Y., "Lean performance evaluation of manufacturing systems: A dynamic and innovative approach," Procedia Computer Science, 3, 388-395, 2011.

[36] Nightingale, D.J. and Mize, J.H., "Development of a lean enterprise transformation maturity model," Information Knowledge Systems Management, Vol. 3 No. 15, 2002.

[37] Raval, Shruti \& Kant, Ravi \& Shankar, Ravi, "Benchmarking the Lean Six Sigma performance measures: a balanced score card approach," Benchmarking: An International Journal, 26, 2019.

[38] Saary, Maria, "Radar plots: A useful way for presenting multivariate health care data,” Journal of clinical epidemiology, 61. 311-7., 2008. 